\title{
Erratum to: Renal pericytes: multifunctional cells of the kidneys
}

\author{
Ania Stefańska • Bruno Péault • \\ John J. Mullins
}

Published online: 22 May 2013

(C) Springer-Verlag Berlin Heidelberg 2013

Erratum to: Pflugers Arch - Eur J Physiol

DOI 10.1007/s00424-013-1263-7

The original publication of this article contains a mistake. Instead of Stefańska AM, Péault B, Mullins JJ, the authors' names should be presented as Ania Stefańska, Bruno Péault, John J. Mullins.

The online version of the original article can be found at http://dx.doi.org/ 10.1007/s00424-013-1263-7.

A. Stefańska $\cdot$ B. Péault · J. J. Mullins $(\bowtie)$

University/BHF Centre for Cardiovascular Science,

The University of Edinburgh, Queens Medical Research Institute,

47 Little France Avenue,

Edinburgh EH16 4TJ Scotland, UK

e-mail: j.mullins@ed.ac.uk

\section{A. Stefańska • B. Péault}

Centre for Regenerative Medicine, University of Edinburgh,

Edinburgh, UK

B. Péault

Orthopaedic Hospital Research Center, University of California,

Los Angeles, CA, USA 